\title{
Ordu Kenti Parklarının Yeterlik ve Ulaşılabilirliği Üzerine Bir Araştırma
}

\author{
An Investigation of the Sufficiency and Accessibility of Parks in the City of Ordu
}

\author{
Kübra Nur BEYLİ ${ }^{a}$, Murat YEŞIL *b \\ ${ }^{l}$ Ordu Üniversitesi, Ziraat Fakültesi, Peyzaj Mimarlı̆̆ı Bölümü, 52200, Altınordu, Ordu
}

• Geliș tarihi / Received: 04.10.2019 • Düzeltilerek geliş tarihi / Received in revised form: 22.02.2020 • Kabul tarihi / Accepted:07.03.2020

\section{Öz}

$\mathrm{Bu}$ çalışmanın amacı Ordu kenti, Altınordu ilçesinde bulunan 78 adet parkın nüfus-alan bağlamında yeterlik ve erişilebilirliklerinin değerlendirilmesidir. Bu çerçevede, parkların büyüklükleri ile bulundukları mahallelerin nüfusları oranlanmış, kişi başına düşen, olması gereken ve ihtiyaç duyulan park alanı gereksinimi tespit edilmiştir. Bu kapsamda; parkların büyüklükleri bulundukları mahallelerin nüfusları ile oranlanmış, kişi başına düşen, olması gereken ve ihtiyaç duyulan park alanları belirlenmiştir. Arcmap 10.0 programı aracılığıyla 1/1000 ölçekli uygulama imar planına noktasal konumları işlenmiş olan parklara, $400 \mathrm{~m}$ yarıçaplı noktasal etkili hizmet alanları oluşturularak parkların erişilebilirlikleri tespit edilmiş ve haritalandırılmıştır. Sonuç olarak, kişi başına $2.40 \mathrm{~m}^{2}$ park alanı düştüğü tespit edilen Altınordu'da, toplamda $416575 \mathrm{~m}^{2}$ park alanı bulunduğu ve standarda ulaşılması adına $15620 \mathrm{~m}^{2}$ alanın daha park olarak değerlendirilmesi gerektiği belirlenmiştir. Mevcut parkların etkili hizmet alanlarının bulundukları mahalleleri büyük oranda kapsadığı ve erişilebilir oldukları görülmüştür. Çalışmanın sonunda elde edilen tüm veriler 1şı̆̆ında tespit edilen sorunlara yönelik çözüm önerilerinde bulunulmuştur.

Anahtar kelimeler: Erişilebilirlik, Ordu, Parklar, Yeterlik

\begin{abstract}
The aim of this study is to examine the adequacy and accessibility of 78 parks in Altinordu district of the city of Ordu according to the size of the parks and the population-area variables. In this sense, the available parking space and the ideal parking space per person were calculated through rating the parking space by the district populations. The sizes of the parks and the population of their neighborhoods were measured and the number of parking areas per person, the amount required and the amounts needed were determined. With the help of the Arcmap 10.0 program, point-to-point service areas were constructed in the 1/1000 scale application development plan and the accessibility of the parks was determined and mapped by creating effective service areas with a radius of 400 meter. In the district of Altinordu where there is a $2.40 \mathrm{~m}^{2}$ park area per person, it is concluded that there is a total park area of $416575 \mathrm{~m}^{2}$ and $15620 \mathrm{~m}^{2}$ area should be considered as a park to reach the standard. It was evaluated that the effective service areas of the existing parks largely cover the neighborhoods where they are located and they are accessible; further, according to the results of the survey, it was obtained that the users prefer coastal parks rather than neighborhood parks. Finally, in light of all the data obtained, solutions were suggested for the problems identified.
\end{abstract}

Keywords: Accessibility, Ordu, Parks, Sufficiency

\footnotetext{
*b Murat YEŞIL; muraty25@hotmail.com, Tel: (0452) 2265200 (dahili: 6325), orcid.org/0000-0002-3643-5626

${ }^{a}$ orcid.org/0000-0002-0965-1251
} 


\section{Giriş}

Kentler, yerleşik hayata geçmiş olan insanların bir arada olma zorunluluklariyla ortaya koydukları, ihtiyaçlarına göre biçimlendirdikleri yaşam mekânlarıdır. İlerleyen dönemlerde kentlerde gelişen ulaşım, sağlik, eğitim ve sosyal olanaklar ile ulaşılan yüksek yaşam standardı ve artan nüfus, fiziksel olarak kentlerin büyümelerini sağlayarak kentleşme sürecini başlatmıştır (Yeşil ve Yüksel, 2016). Kentleşmenin yoğun olarak görüldüğü alanlarda kentli; çevresel sorunlar, yoğun iş temposu, monotonluk ve serbest zaman azlığ1 gibi birçok sorunla karşı karşıya kalmıştır. İnsanlar bu tür olumsuzluklardan, uzaklaşmak için rekreasyon amaçlı açık-yeşil alanlara yönelmeye başlamıştır. Teknolojik gelişmelerle insanların serbest zamanlarının artışı, eğitim ve gelir düzeylerinin yükselmesi ile yaşam sürelerinin uzaması gibi etkenler açik-yeşil alanlarda yapılabilen rekreasyonel etkinliklere olan talebi artmıştır (Mansuroğlu, 2002).

Açık-yeşil alanlar, insan ile doğa arasındaki bozulan ilişkinin dengelenmesini ve kentsel yaşam koşullarının iyileştirilmesini sağlayan, kente kimlik kazandıran, rekreasyonel bakımdan kullanım potansiyeli olan kentsel alanlardır. $\mathrm{Bu}$ alanlar, kentlinin yaşadığı yerden zevk almasını, dinlenmesini, eğlenmesini, dolaşmasını, spor yapmasını sağlayan ve kendine has bir kimliği olan açık hava odaları niteliğindedir (Thompson, 2002). Kentsel yerleşim planları incelendiğinde, kent içerisinde bulunan açık-yeşil alanların bazen belli planlar çerçevesinde bazen de plansız olarak kendiliğinden oluşabildiği görülmektedir. Her iki durumda da kentsel açık ve yeşil alan normları; kentin coğrafi konumu, fiziksel, demografik, doğal, politik ve mimari yapısı gibi değişkenler doğrultusunda belirlenmektedir (Gül ve Küçük, 2001). Yeşil alanların kent genelindeki dağılımlarında, kent insanının sosyal, kültürel ve ekonomik yapısı, yeşil alanların içerdikleri fonksiyonel özellikler, fonksiyonların yeterliliği, fonksiyonlar arasında ilişki, hizmet ettiği kitle nüfus ve hizmet alanı dikkate alınmalıdır (Atabeyoğlu ve Bulut, 2012). Farklı kentsel aktivitelerin gerçekleştiği arazi kullanımlarında farklı yeşil alan ihtiyaçları olacağından, yeşil alan standartlarının belirlenmesinde, kentsel alanda geçerli olan aktiviteler ve diğer arazi kullanımları da göz önünde bulundurulmalıdır (Aksoy, 2014).

Pamay, (1978)'a göre; kent içerisinde ve çevresinde bulunan yeşil alanların fiziksel ve organik bir yapıya sahip olabilmeleri için dengeli dağılmaları, mekânsal kurgularla uyumlu olmaları ve ihtiyaçlara cevap verecek nitelik ile nicelikte olmaları gereklidir. Açık ve yeşil alan varlığının korunması ve planlı gelişmesi sağlanarak, ulusal standartlar düzeyinde olması sağlanmalıdır. Türkiye standartlarına göre belirlenmiş olan açık ve yeşil alan normları farklı araştırıcılardan derlenerek, minimum ve maksimum değerleri Tablo 1'de verilmiştir.

Tablo 1. Türkiye koşulları için önerilen açık ve yeşil alan standartları (Pamay, 1978; Nasuh, 1993; Ersoy, 2015)

\begin{tabular}{|c|c|c|c|c|}
\hline \multirow{2}{*}{ Açık ve Yeşil Alan Türü } & \multicolumn{3}{|c|}{ Kişi Başına Düşen $\mathbf{m}^{2}$} & \multirow{2}{*}{$\begin{array}{l}\text { Minimum Alan } \\
\text { Büyüklüğü (da) }\end{array}$} \\
\hline & Ort. & Min. & Max. & \\
\hline Çocuk Oyun Bahçesi & 1.0 & 0.5 & 4.5 & 12 \\
\hline Spor ve Oyun Alanları & 4.0 & 2.5 & 8.5 & 40 \\
\hline Kent Bahçeleri & 0.25 & - & - & 5 \\
\hline Mahalle Parkı & 2.5 & - & - & 8 \\
\hline Semt Parkı & 5.0 & - & - & 50 \\
\hline Kent Parkı & 10.0 & 10 & 40 & 400 \\
\hline Botanik ve Hayvanat Bahçesi & 0.5 & - & - & 100 \\
\hline Sergi Parkları (Lunapark) & 0.2 & 0.1 & 0.5 & 100 \\
\hline Koru ve Orman & 5.0 & 3.0 & 9.0 & 2000 \\
\hline Çayırlık (Doğal) & 5.0 & - & - & 50 \\
\hline
\end{tabular}


Yeşil alan standartları ülkeden ülkeye farklılıklar göstermektedir. Ülkemizde yeşil alan normlarına yönelik ilk gelişme 1933 yılında yayımlanan 2290 sayılı Yap1 Yollar Kanununda belirlenmiştir. Kanunun 4. maddesine göre kişi başına $65 \mathrm{~m}^{2}$ lik kent alanı ayrılmıştır. Bu ayrılan alan içerisinde yeşil alanlar, koruluklar, çayırlıklar ve oyun yerleri için kişi başına $4 \mathrm{~m}^{2}$ alan ayrılması önerilmiştir. 1985 tarihli 3194 sayılı İmar Kanununda bu oran kişi başına $7 \mathrm{~m}^{2}$ ye yükseltilmiştir. 1999 yılı 23804 sayılı resmi gazetede yayımlanan "İmar Planı Yapılması ve Değişikliklerine Ait Esaslara Dair Yönetmelik" hükmüne göre, kent içerisinde kişi başına $10 \mathrm{~m}^{2}$ aktif yeşil alan, belediye ve mücavir alan sınırları dışında ise kişi başına $14 \mathrm{~m}^{2}$ aktif yeşil alan düşecek şekilde planlaması gerektiği belirtilmiştir. 2014 yılı 29030 sayılı Resmî Gazetede yayımlanarak yürürlüğe giren "Mekânsal Planlar Yapım Yönetmeliği" hükmüne göre, ilçe sınırları dahilinde yapılan planlamalarda açık yeşil alanların kişi başına $10 \mathrm{~m}^{2}$, il sınırı bütününde yapılan planlamalarda ise kişi başına $5 \mathrm{~m}^{2}$ düşecek şekilde planlanması gerekmektedir.

Açık ve yeşil alanlar "haklar, ihtiyaçlar ve anlam" çevresinde 3 boyut kazanarak tasarlanmalıdır (Francis, 2003). Belirtilmiş olan bu 3 boyut kapsamında açı ve yeşil alanların kamusal alan olduğu, halkın her kademesine hitap etmesi gerektiği ve herkes için farklı bir anlam ifade ettiği vurgulanmaktadır. Açık yeşil alanların planlanmasında ve tasarımında alanların bir çevresel kimliğe sahip olmasına ve toplumsal değerler göz önünde bulundurularak uygulamaların yapılmasına dikkat edilmesi gerekmektedir. Tasarımda, mekansal kapalılık, sinırların devamlılığı, sirkülasyon, yönlendirme, işlevsellik, estetik, düzen gibi tasarım elemanları dikkate alınarak, kent-mekân ve kitle-boşluk oranları belirlenerek bu oranlar doğrultusunda çalışmalar yapılmalı, yeşil alanlar farklı yeşil yollar veya ulaşım güzergâhları ile birbirine bağlanmalıdır (Kart, 2002). Açık ve yeşil alanlar nicelik ve nitelik bakımdan kentlinin ihtiyaçlarına cevap verecek düzeyde olmalıdır.

Kentlerde bulunan açık ve yeşil alanlar kentlerin sürdürülebilirliği ve yaşam kalitesinin arttırılmasında büyük bir rol üstlenmektedir. Yeşil alan sistemi içerisinde yer alan parklar kentsel yaşamın getirdiği birçok etkiyle doğadan uzaklaşmakta olan insanların tekrar doğaya yönelmelerine imkân sunan, peyzaj tasarım elemanları ile düzenlenmiş alanlardır (Nasuh, 1993). Bu alanlar, insanları fiziksel ve psikolojik yönden iyileştiren, toplumlar arasında bağ1 güçlendiren, yaşamak ve çalışmak için kentleri çekici hale getiren mekânlardır (Sherer, 2003). Yerleşim yerlerinin farklı bölümlerinde ve çevresinde yapılmış olan parklar, halkın her yaş grubuna hitap ederek, aktif ve pasif karakterli rekreasyon ihtiyacına cevap veren sosyal yeşil alan niteliği taşımaktadır (Tanrıverdi, 1987). Çeşitli büyüklüklere sahip olan parklarda en önemli tasarım ögesi, parkların algılanabilir ve okunabilir nitelikte olmasıdır. Alanlar içerisinde halkın kullanımını teşvik edecek yapay ve doğal peyzaj elemanları bir arada kullanılmalıdır. Parklarda yer alacak etkinlik alanları bir birini tamamlayan ve gruplayan bir biçimde olmalı ve birbirlerinden belirli hatlar ile ayrılmalıdır (Aydemir, 2004). Ayrıca parklar, kentte görülen monoton ve katı silüeti yumuşatarak kente hareket katan kentsel tasarımın en önemli elemanıdır. Parklar; büyüklükleri ve etkili hizmet alanı, alan kullanımları, coğrafi özellikleri ve kullanıcı profilleri bakımından; milli parklar, bölge parkları, kent parkları, mahalle parkları, çocuk oyun alanları, spor alanları, hayvanat bahçeleri ve botanik parkları şeklinde sınıflara ayrılmaktadır (Gürsoy, 2018).

Sinıflandırmalarda yer alan ve en küçük yeşil alan birimi olan mahalle parkları kentlinin rekreasyonel faaliyetlerini gerçekleştirdikleri, kent dokusu içerisinde geçiş alanı niteliği taşımaktadır (Ersoy, 1994).

Y1ldızc1 (1982), mahalle parklarını; alanı en az 8 da olan ve konutların 400-800 m yakınında, yoğun yerleşim grubuna hizmet eden yeşil alan birimi olarak tanımlamıştır. Mahalle parkları; konum ve topografik özellikleriyle sadece bir mahalleye değil, yakın çevredeki birçok mahalleye hizmet edebilecek büyüklükte ve $800-1200 \mathrm{~m}$ yaya ulaşım mesafesinde planlanmalıdır (Uzun, 1990). Yenice (2012)'ye göre ise ideal yürüyüş süresi ve kentsel yeşil alanların işlevleri-kullanıcı gruplarına dayalı olarak erişebilirlik mesafelerinin; çocuk oyun alanları için 400 metre, semt-mahalle parkı ve spor tesisi alanları için 800 metre olmas1 gerekmektedir.

Simonds (1961), mahalle parkları için 1000 kişiye 1.2 ha alan ve mahalle kümesi parkları için 1000 kişiye 2 ha alan düşmesi gerektiğini belirtmiştir. Pamay (1978)'a göre, Türkiye koşulları için önerilen açık ve yeşil alan standartlarında ise mahalle parklarının kişi başı ortalama $2.5 \mathrm{~m}^{2}$ olmas1 gerekmektedir (Nasuh, 1993).

Bu çalışma ile Ordu kenti, Altınordu ilçesinde bulunan 78 adet parkın, nüfus-alan bağlamında 
yeterlik ve erişilebilirliklerinin değerlendirilmesi amaçlanmaktadır. $\mathrm{Bu}$ kapsamda, parkların büyüklükleri ile bulundukları mahallelerin nüfusları oranlanmış, kişi başına düşen, olması gereken ve ihtiyaç duyulan park alanı gereksinimi tespit edilmiştir. Arcmap 10.0 programı aracılığıyla 1/1000 ölçekli uygulama imar planına noktasal konumları işlenmiş olan parklar için 400 $\mathrm{m}$ yarıçaplı noktasal etkili hizmet alanları oluşturularak erişilebilirlik olanakları haritalandırılmıştır. $\mathrm{Bu}$ çerçevede, parkların Altınordu ilçesine ne derece hizmet ettiği belirlenmiş ve yeşil alan ihtiyaçlarına göre önerilerde bulunulmuştur.

Mahalle parkları konutların 400-800 m yakınında yoğun yerleşim gruplarına hizmet eden kent dokusu içerisinde yer alan yeşil alanlardır (Yıldızc1, 1982). Mahalleler içinde bulunan çocuk oyun alanlarının konutlara uzaklığ $400-800 \mathrm{~m}$ ulaşım mesafesinde olmalıdır (Tanrıverdı, 1987). 15.000 kişi nüfusa sahip olan mahallelerde İmar planına göre bir ya da birden fazla mahalleye (1015 bin kişi) hizmet veren, hizmet yarıçapının 800 ile $1000 \mathrm{~m}$ arasında olmas1 gerekmektedir.
Çalışma kapsamında incelenmiş olan mahalle parkları bulunduğu mahalle bazında incelendiğinden ve parkların çoğunda çocuk oyun alanı bulunduğundan parkların ulaşım mesafeleri $400 \mathrm{~m}$ yarıçaplı etkili hizmet alanı çerçevesinde incelenmiştir.

Çalışmanın materyalini Ordu Büyükşehir Belediyesi merkez ilçesi olan Altınordu Belediyesi merkez mahallelerinde bulunan toplamda $416575 \mathrm{~m}^{2}$ alana sahip 78 adet mahalle park1 oluşturmaktadır (Şekil 1).

$\mathrm{Bu}$ parklar; kendine özgü sosyal ve mimari yapısı bulunan merkez mahalleleri içerisinde yer almaktadır. Mahalle sakinlerinin dinlenmesine, eğlenmesine, sosyalleşmesine ortam sağlayan mahalle parkları kentsel açık-yeşil alanların en küçük birimlerinden biridir. Mahallenin karakteristik özelliklerine göre düzenlenmiş olan bu parklar, dinlenme alanları, çocuk oyun alanları ve spor alanları ile her yaş grubuna hitap ederek insanların günlük rekreasyonel gereksinimlerini karşılayabilecekleri alan kullanımlarını içermektedir.

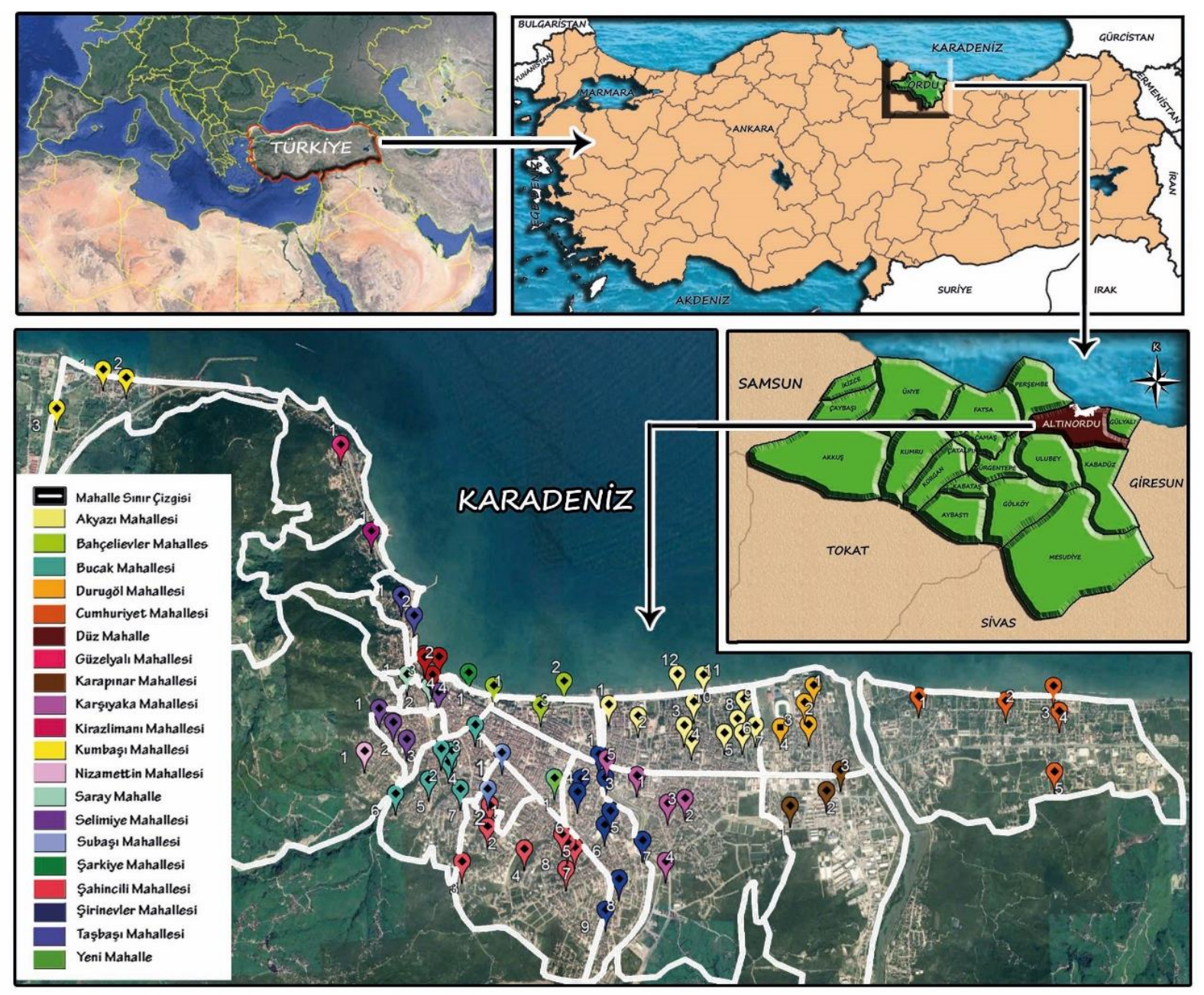

Şekil 1. Ordu kenti konumu, mahalle sınırları ve parkların konumları 


\section{Yöntem}

Çalı̧̧manın yöntemi, konu ile ilgili literatür taraması-veri toplama, saha çalışması, analizsentez ve öneriler olmak üzere dört aşamadan oluşmaktadır. Çalışma süreci içerisinde öncelikle konu ile ilgili yapılmış çalışmalar incelenmiştir. İlk aşamada; park alanları için ideal alan büyüklüğü ve erişilebilirlik sınır değerlerini belirlemek için literatür taraması yapılmıştır.

İkinci aşamada; parkların alan büyüklükleri ile bulundukları mahallelerin nüfusları oranlanmış, kişi başına ortalama $2.5 \mathrm{~m}^{2}$ park alanı olması gerektiği standardı (Pamay, 1978; Nasuh, 1993) üzerinden kişi başına düşen, olması gereken ve ihtiyaç duyulan park alanı miktarları tespit edilmiştir.

Üçüncü aşamada; Ordu kent merkezinde bulunan parkların erişilebilirliklerini tespit etmek için 1/1000 ölçekli Uygulama İmar Planı, CBS yazılımı Arcmap 10.0 programına aktarılmıştır. Ordu Büyükşehir Belediyesi ve Altınordu Belediyesinden alınan park konumlarına göre Uygulama İmar planı üzerinde parklar noktasal olarak belirlenmiş ve konumlar üzerine $400 \mathrm{~m}$ yarıçaplı etkili hizmet alanları oluşturulmuştur (Yıldızc1, 1982; Kandemir, 2010). Oluşturulan etki alanlarına göre parkların mahalle ölçeğinde erişilebilirlik durumu tespit edilmiş ve ilgili mevzuat erişme mesafeleri bağlamında değerlendirilmiştir. $\mathrm{Bu}$ yöntem kurgusu kapsamında Ordu kenti 1/1000 ölçekli harita kullanılarak mahalle üniteleri düzeyinde yapılan ölçümler ile elde edilen niceliksel veriler ile erişilebilirlik haritaları oluşturulmuştur.

Son aşamada ise; Ordu kent merkezinde bulunan park alanlarının mevcut durumları etki alanları ve erişim mesafeleri bağlamında değerlendirilerek, yeterlik ve eksikliklere yönelik çözüm önerilerinde bulunulmuştur.

\section{Bulgular}

Altınordu ilçesi merkez mahallelerinde imar planı esas olmak üzere toplamda $416575 \mathrm{~m}^{2}$ alana sahip 78 adet mahalle parkı bulunmaktadır. Parkların 8'i kullanıcılara sadece dinlenme imkanı sunarak pasif rekreasyon ihtiyacina cevap verecek özellikler taşımaktadır, 19'u dinlenme alanı ve çocuk oyun alanlarından oluşmaktadır, 27'sinde dinlenme alanı, çocuk oyun alanı ve fitness ekipmanları bulunmaktadır. 24 parkta ise dinlenme, oyun, spor, piknik vb. aktif rekreasyon etkinliklerine tam anlamiyla hizmet sunan alan kullanımları yer almaktadır.

1/1000 ölçekli uygulama imar planına işlenmiş olan parkların noktasal konumları üzerine $400 \mathrm{~m}$ yarıçaplı noktasal etkili hizmet alanları oluşturulup alanların erişilebilirlikleri belirlenmiştir. Parklar bulundukları mahalle özelinde incelendiğinde;

kıyı yerleşkesi olan Akyazı Mahallesi 1649.64 da yüzölçümü ile Altınordu ilçesinin \%7.28'lik kısmını kapsamaktadır. 17430 kişi nüfusa sahip olan mahallede nüfus yoğunluğu $10 \mathrm{kişi} / \mathrm{km}^{2}$ 'dir. Mahallede toplamda $110354 \mathrm{~m}^{2}$ alana sahip 12 adet park bulunmaktadır (Şekil 2). Mahalle düzeyinde yapılan hesaplamada Akyazı mahallesinde kişi başına $6.33 \mathrm{~m}^{2}$ park alanı düşmektedir (Tablo 2). Erişilebilirlik kapsamında parkların; Akyazı Mahallesine tamamen, Bahçelievler, Durugöl ve Karşıyaka Mahallelerine de kısmen hizmet ettiği görülmüştür (Şekil 10).

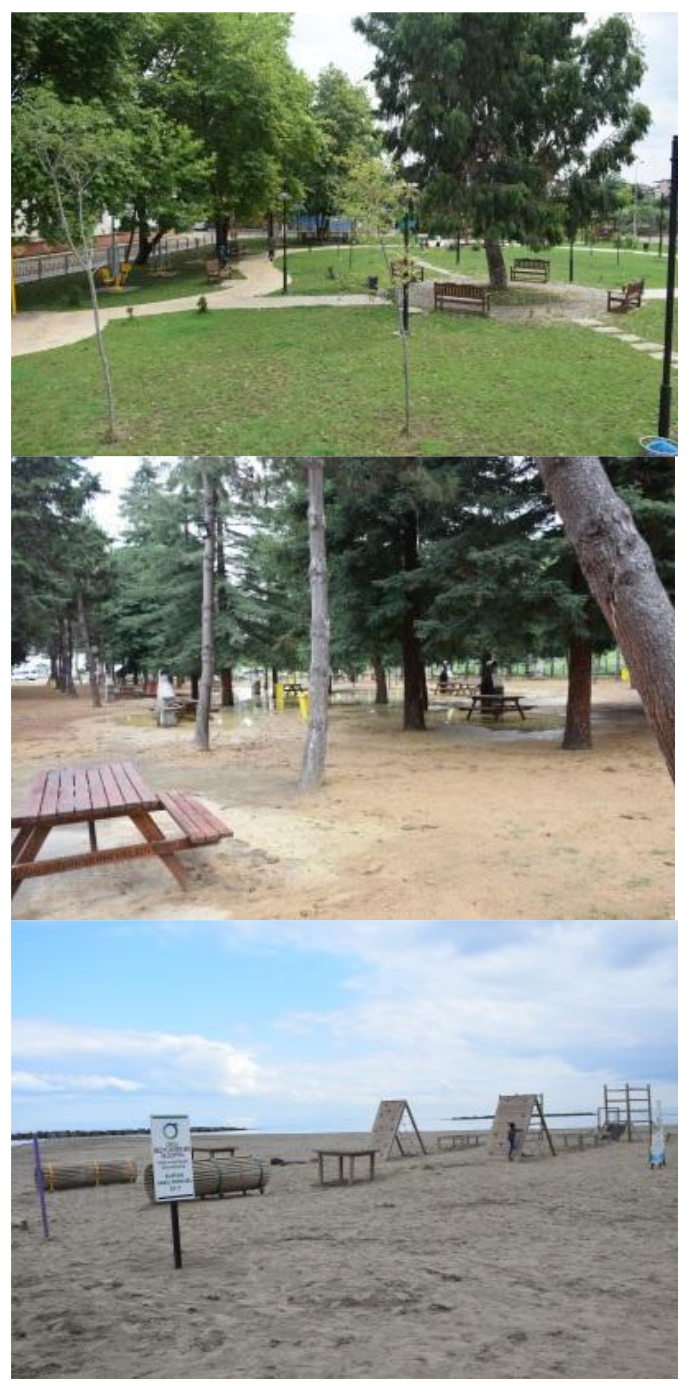

Şekil 2. Akyazı mahallesi parkları genel görünümü 
Eski yerleşim alanlarından biri olan Aziziye Mahallesi 92.19 da yüz ölçümü ile Altınordu ilçesinin \%0.40’l1k kısmını kapsamaktadır. 930 kişi nüfusa sahip olan mahallenin nüfus yoğunluğu 10 kişi $/ \mathrm{km}^{2}$ 'dir. 1979 yılında "Gayrimenkul Eski Eserler ve Anitlar Kurulu" tarafından bir kısmı kentsel sit alanı ilan edilmiş olan mahallede park bulunmamaktadır. Mahallede kişi başına $2.5 \mathrm{~m}^{2}$ park alanı standardının sağlanması için $2.325 \mathrm{~m}^{2}$ park alanına ihtiyaç duyulmaktadır (Tablo 2).

Kıyı yerleşkesi olan Bahçelievler Mahallesi topografik olarak düz bir yapıya sahiptir. 572.28 da yüz ölçümü ile Altınordu ilçesinin \%2.52'lik kısmını kapsamaktadır. Nüfusu 8419 kişi olan mahallede nüfus yoğunluğu $14 \mathrm{kişi} / \mathrm{km}^{2}$ 'dir. Mahallede toplamda $81450 \mathrm{~m}^{2}$ yüzölçümüne sahip 3 adet park bulunmakta (Şekil 3) olup kişi başına $9.67 \mathrm{~m}^{2}$ park alanı düşmektedir (Tablo 2). Parklar erişilebilirlik kapsamında incelendiğinde; Bahçelievler Mahallesinin neredeyse tamamına ve sinır mahallesi olan Yeni Mahalle ile Şarkiye Mahallesine de büyük oranda hizmet ettikleri belirlenmiştir (Şekil 10).

Bucak Mahallesi 979.48 da yüz ölçümü ile Altınordu İlçesinin \%4.32'lik kısmını kapsamaktadır. Nüfusu 16642 kişi olan mahallede $\mathrm{km}^{2}$ 'ye 16 kişi düşmektedir. Mahallede toplamda $5130 \mathrm{~m}^{2}$ alana sahip 7 adet park bulunmakta olup kişi başına $0.33 \mathrm{~m}^{2}$ park alanı düşmektedir (Tablo 2). Erişilebilirlik kapsamında parkların Bucak Mahallesi sakinleri açısından erişilebilir olduğu, Yeni, Şarkiye, Subaşı ve Selimiye Mahallelerine de kısmen hizmet ettiği ortaya çıkmıştır.

Üniversite ana yerleşkesinin de bulunduğu ve yerleşim bakımından gelişmekte olan Cumhuriyet Mahallesi 4051.33da yüz ölçümü ile Altınordu ilçesinin \%17.8'lik kısmını kapsamaktadır. Nüfusu 9379 kişi olan mahallede nüfus yoğunluğu $2.31 \mathrm{kişi} / \mathrm{km}^{2}$ dir. Mahallede toplamda $13673 \mathrm{~m}^{2}$ yüz ölçüme sahip 5 adet park bulunmakta olup kişi başına $0.68 \mathrm{~m}^{2}$ park alanı düşmektedir. Parkların alan ve fonksiyon açısından yetersiz olduğu ve mahalle sakinleri açısından tam anlamıla erişilebilir olmadığ tespit edilmiştir (Şekil 10).

Kıyı yerleşkesi olan Durugöl Mahallesi 1309.11da yüzölçümü ile Altınordu ilçesinin \%5.78'lik kısmını kapsamaktadır. 8045 kişi nüfusa sahip olan mahallede nüfus yoğunluğu 6.14 kişi $/ \mathrm{km}^{2}$ 'dir. Mahallede toplamda $13395 \mathrm{~m}^{2}$ alana sahip 4 adet park bulunmakta olup kişi başına $1.66 \mathrm{~m}^{2}$ park alanı düşmektedir. Parkların etkili hizmet alanının Durugöl Mahallesini tamamen, Akyazı ve Karapınar mahallelerini ise kısmen kapsadığı görülmüştür (Şekil 10).

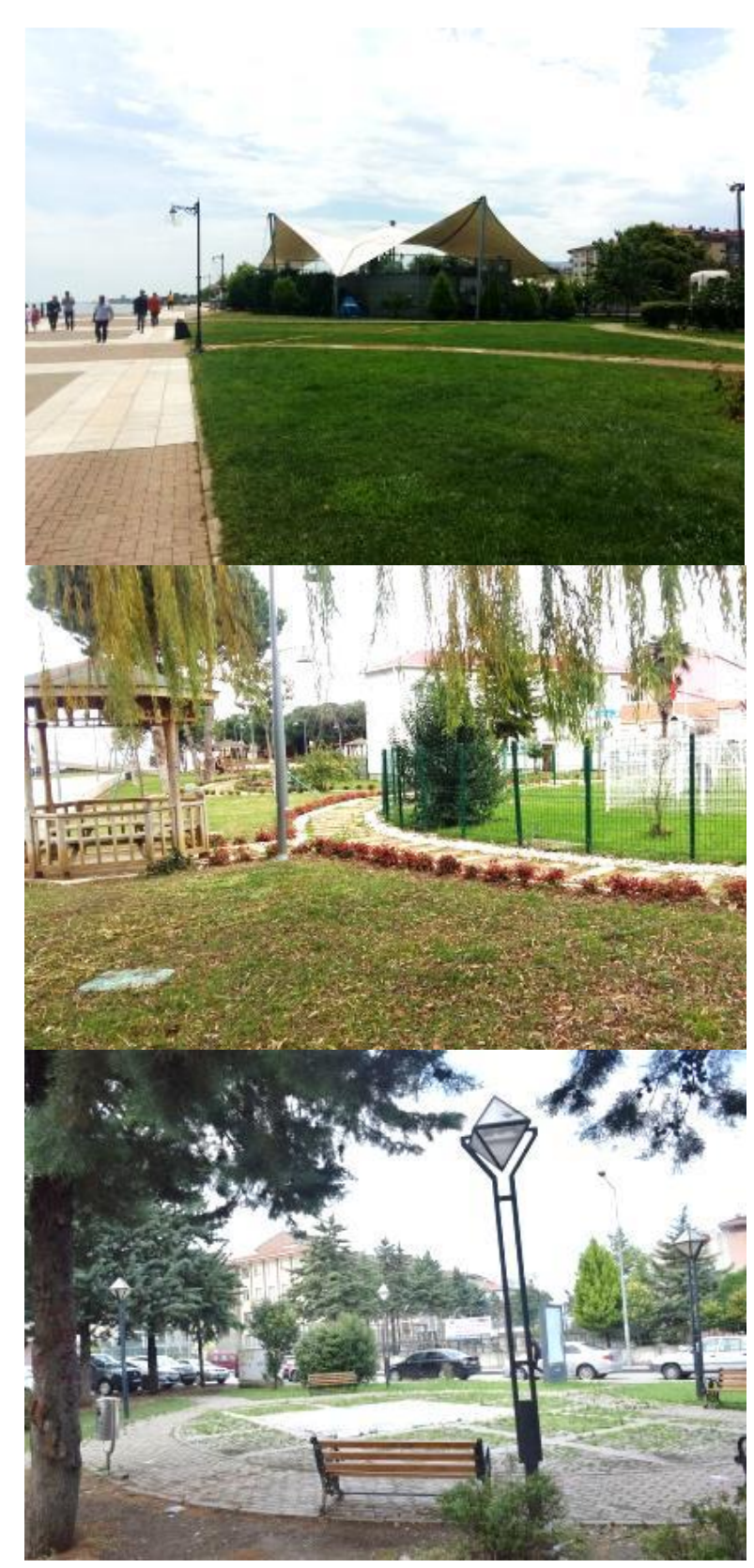

Şekil 3. Bahçelievler mahallesi parkları genel görünümü

Altınordu ilçesinin merkezi konumunda olan Düz Mahalle, 135.63 da yüz ölçümü ile ilçenin \%0.59'luk kısmını kapsamaktadır. 1762 kişi nüfusa sahip olan mahallede nüfus yoğunluğu 12 kişi $/ \mathrm{km}^{2}$ 'dir. Mahallede toplamda $22860 \mathrm{~m}^{2}$ alana sahip 4 park bulunmaktadır (Şekil 4). Kişi başına $12.90 \mathrm{~m}^{2}$ park alanı düşen mahalledeki parklar, erişilebilirlik kapsamında incelendiğinde; Düz mahalle açısından tam anlamıyla, sınır mahalleleri olan Zaferimilli, Aziziye, Şarkiye, Saray ve Selimiye mahallelerine ise kısmen erişilebilir olduğu belirlenmiştir (Şekil 10). 


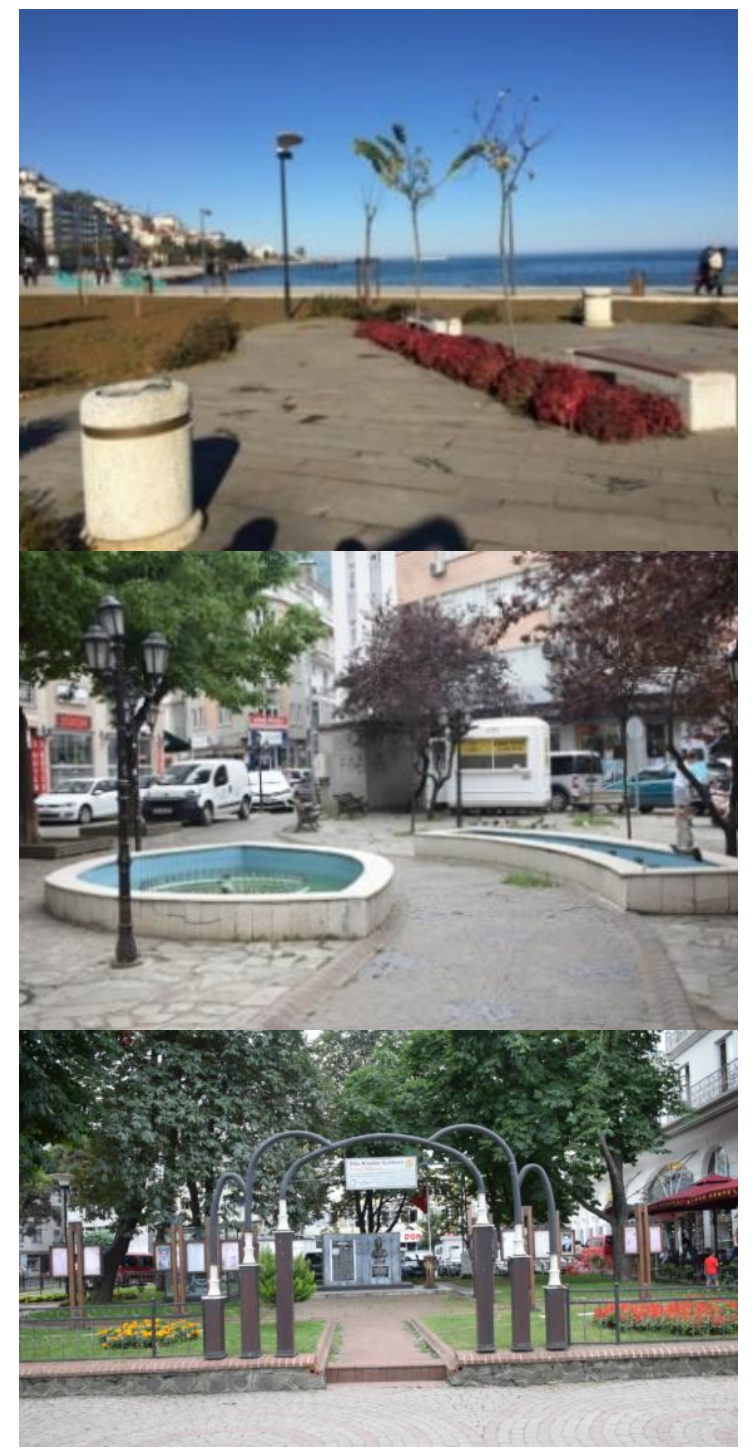

Şekil 4. Düz mahalle parkları genel görünümü

Topografik olarak eğimli bir yapıya sahip olan Güzelyalı Mahallesi 389.66 da yüz ölçümü ile Altınordu ilçesinin \%1.72'lik kısmını kapsamaktadır. Nüfusu 2286 kişi olan mahallede nüfus yoğunluğu $5.8 \mathrm{kişi} / \mathrm{km}^{2}$ 'dir. Mahallede $2.000 \mathrm{~m}^{2}$ alana sahip 1 adet park bulunmakta olup kişi başına $0.87 \mathrm{~m}^{2}$ park alanı düşmektedir. Parkın, bulunduğu mahalle açısından yetersiz kaldığ 1 ve erişilebilir olmadığ tespit edilmiştir.

Sanayi bölgesi olan Karapınar Mahallesi 2055.88 da yüz ölçümü ile Altınordu ilçesinin \%9.07'lik kısmını kapsamaktadır. 3355 kişi nüfusa sahip olan mahallede nüfus yoğunluğu 1.63 kişi $/ \mathrm{km}^{2}$ 'dir. Mahallede toplamda $8600 \mathrm{~m}^{2}$ alana sahip 3 adet park (Şekil 5) bulunmakta olup kişi başına $2.56 \mathrm{~m}^{2}$ park alanı düşmektedir. Parkların Karapınar mahallesine büyük oranda, sınır mahalleleri olan Durugöl ve Karşıyaka Mahallelerine ise kismen hizmet ettikleri görülmektedir (Şekil 10).

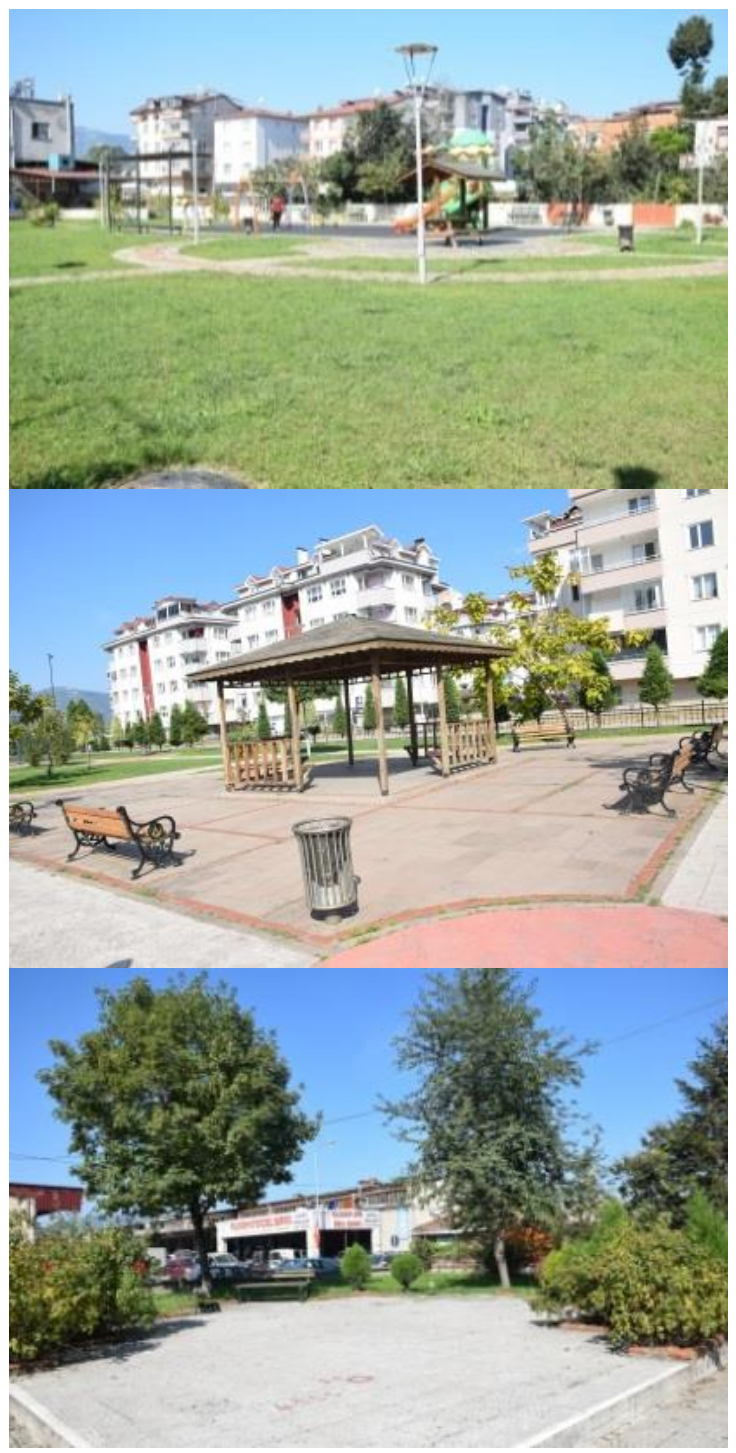

Şekil 5. Karapınar mahallesi parkları genel görünümü

Yerleşim bakımından gelişmekte olan Karşıyaka Mahallesi 2282.26 da alanı ile Altınordu ilçesinin \%10'luk kısmını kapsamaktadır. Nüfusu 16195 kişi olan mahallede nüfus yoğunluğu 7 $\mathrm{kişi} / \mathrm{km}^{2}$ dir. Mahallede toplamda $12150 \mathrm{~m}^{2}$ alana sahip 5 adet park bulunmakta olup kişi başına $0.72 \mathrm{~m}^{2}$ park alanı düşmektedir. Parkların, bulundukları mahalleye büyük oranda, Şirinevler Mahallesine ise kısmen hizmet ettiği görülmüştür (Şekil 10).

Eski yerleşim alanlarından olan Kirazlimanı Mahallesi 396.40 da yüz ölçümü ile Altınordu ilçesinin \%1.75'lik kısmını kapsamaktadır. 1039 kişi nüfusa olan mahallede nüfus yoğunluğu 2.6 kişi $/ \mathrm{km}^{2}$ 'dir. Mahallede $600 \mathrm{~m}^{2}$ alana sahip 1 adet park bulunmakta olup kişi başına $0.57 \mathrm{~m}^{2}$ park alanı düşmektedir (Şekil 10).

Deniz kıyısı yerleşkesi olan Kumbaşı Mahallesi 1374.91 da yüz ölçümü ile Altınordu ilçesinin 
\%6.07'lik kısmını kapsamaktadır. 1705 kişi nüfusa olan mahallede nüfus yoğunluğu 1.24 kişi $/ \mathrm{km}^{2}$ 'dir. Mahallede toplamda $5984 \mathrm{~m}^{2}$ alana sahip 3 adet park bulunmaktadır (Şekil 6). Kişi başına $3.50 \mathrm{~m}^{2}$ park alanı düşen mahallede, parkların mahalle sakinleri açısından erişilebilirlik sınırları içerisinde oldukları belirlenmiştir (Şekil 10).
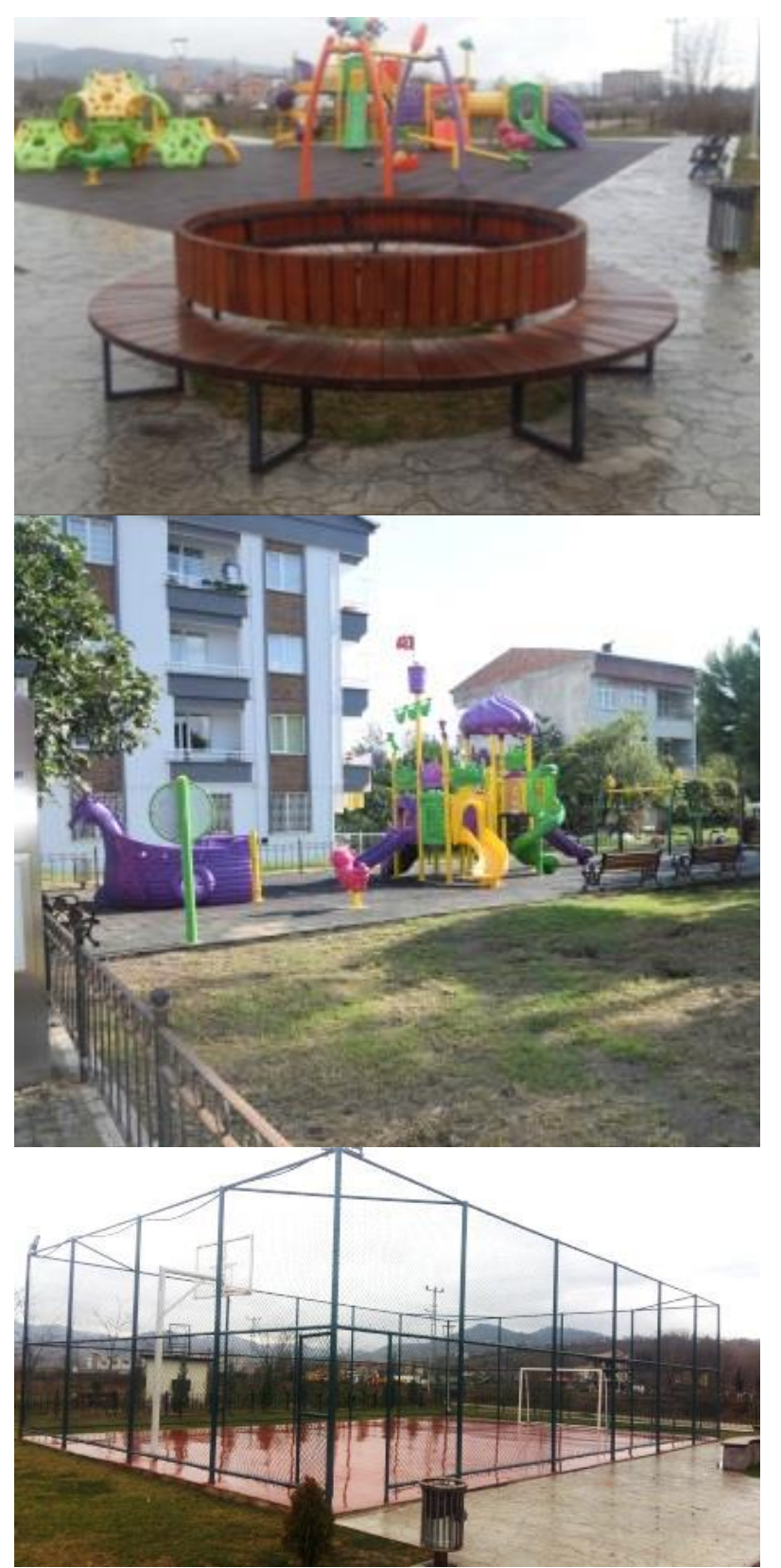

Şekil 6. Kumbaşı mahallesi parkları genel görünümü

Eski yerleşim alanlarından olan Nizamettin Mahallesi 192.90 da yüz ölçümü ile Altınordu ilçesinin \%0.63'lük kısmını kapsamaktadır. Nüfusu 4523 kişi olan mahallede nüfus yoğunluğu $23 \mathrm{kişi} / \mathrm{km}^{2}$ 'dir. Mahallede $1000 \mathrm{~m}^{2}$ alana sahip 1 adet park bulunmakta olup kişi başına $0.22 \mathrm{~m}^{2}$ park alanı düşmektedir. Erişilebilirlik kapsamında parkın bulunduğu mahalleye büyük oranda ve Selimiye Mahallesine de kısmen hizmet ettiği görülmüştür (Şekil 10).

101.65 da yüz ölçümüne sahip olan kent merkezi niteliğindeki Saray Mahallesi, Altınordu ilçesinin $\% 0.33$ 'lük kısmını kapsamaktadır. Nüfusu 1282 kişi olan mahallede nüfus yoğunluğu 12 $\mathrm{kişi} / \mathrm{km}^{2}$ dir. Mahalle toplamda $4750 \mathrm{~m}^{2}$ alana sahip 2 adet park bulunmaktadır. (Şekil 7). Kişi başına $3.70 \mathrm{~m}^{2}$ park alanı düşen mahallede parkların; Saray, Aziziye ve Düz Mahalleye tamamen, Şarkiye Mahallesine büyük oranda ve Selimiye Mahallesine ise kısmen hizmet ettikleri görülmektedir (Şekil 10).

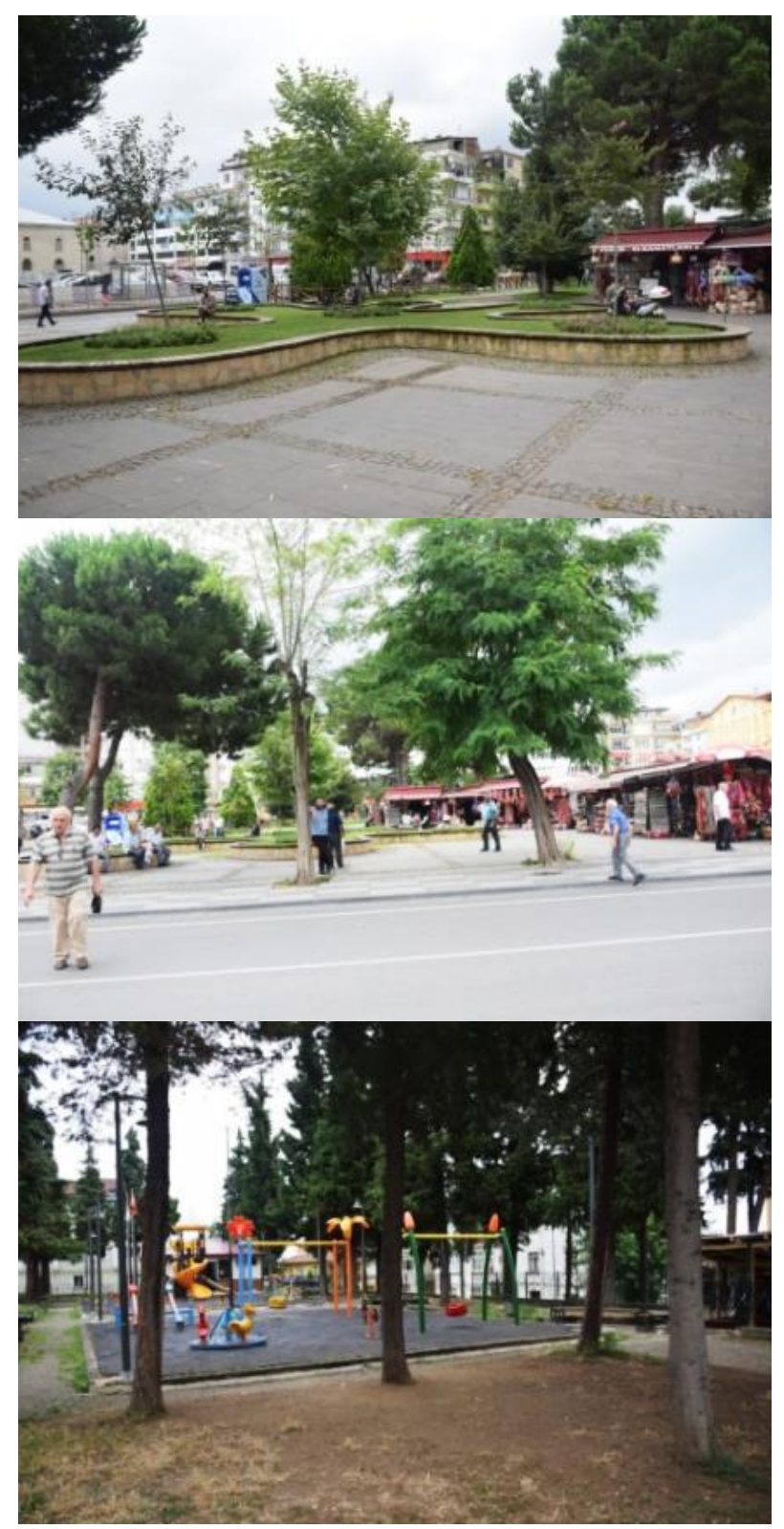

Şekil 7. Saray mahallesi parkları genel görünümü 
Selimiye Mahallesi 550.41 da yüz ölçümü ile Altınordu İlçesinin \%2.43'lük kısmını kapsamaktadır. Nüfusu 9482 kişi olan mahallede nüfus yoğunluğu $17 \mathrm{kişi} / \mathrm{km}^{2}$ 'dir. Mahallede toplamda $9800 \mathrm{~m}^{2}$ alana sahip 4 adet park bulunmakta olup kişi başına $1.03 \mathrm{~m}^{2}$ park alanı düşmektedir. Parklar erişilebilirlik bakımından incelendiğinde; Selimiye Mahallesine tamamen, Düz, Şarkiye ve Saray Mahallelerine büyük oranda, Nizamettin ve Düz Mahallelerine ise kısmen hizmet ettiği görülmüştür.

Subaşı Mahallesi 264.96 da yüz ölçümü ile Altınordu ilçesinin \%1.17'lik kısmını kapsamaktadır. 8532 kişi nüfusa sahip olan mahallede nüfus yoğunluğu $32 \mathrm{kişi} / \mathrm{km}^{2}{ }^{\text {' }} \mathrm{dir}$. Mahallede toplam $2900 \mathrm{~m}^{2}$ alana sahip 2 adet park bulunmaktadır. Kişi başına $0.33 \mathrm{~m}^{2}$ park alanı düşen mahallede parklar, Subaşı Mahallesine tamamen, Bucak, Şahincili ve Yeni Mahalleye ise kısmen hizmet edebilmektedir (Şekil 10).

Gelişmekte olan yerleşim alanlarına sahip Şahincili Mahallesi 2054.29 da yüz ölçümü ile Altınordu İlçesinin \%9.07'lik kısmını kapsamaktadır. 24426 kişi nüfusa sahip olan mahallede nüfus yoğunluğu $11 \mathrm{kişi} / \mathrm{km}^{2}$ 'dir. Mahallede toplamda $24260 \mathrm{~m}^{2}$ alana sahip 8 adet park bulunmakta olup kişi başına $1.00 \mathrm{~m}^{2}$ park alanı düşmektedir. Parklar etkili hizmet alanı bakımından incelendiğinde Şahincili ve Subaşı Mahallelerini büyük oranda kapsamakta, Şirinevler Mahallesi ise kısmen bu alan içerisine girebilmektedir.

Kent merkezi konumundaki Şarkiye Mahallesi 787 da yüz ölçümü ile Altınordu'nun \%3.47'lik kısmını kaplamaktadır. Nüfusu 3781 kişi olan mahallede nüfus yoğunluğu $4.8 \mathrm{kişi} / \mathrm{km}^{2}$ 'dir. Mahallede $53000 \mathrm{~m}^{2}$ alana sahip 1 adet park bulunmaktadır (Şekil 8). Kişi başı $14.0 \mathrm{~m}^{2}$ park alanı düşen mahallede kıyı parkı niteliğindeki bu park, konumu itibariyle çekim merkezi haline gelmiştir. Dolayısıyla kentin geneline hizmet ettiğini söylemek mümkündür.

Yerleşim bakımından gelişmekte olan Şirinevler Mahallesi 1306.22 da yüz ölçümü ile Altınordu'nun \%5.76'lık kısmını kapsamaktadır. Nüfusu 15567 kişi olan mahallede nüfus yoğunluğu $11 \mathrm{kişi} / \mathrm{km}^{2}$ ' dir. Mahallede toplamda $24306 \mathrm{~m}^{2}$ alana sahip 9 adet park bulunmakta olup kişi başına $1.56 \mathrm{~m}^{2}$ park alanı düşmektedir. Parklar erişilebilirlik kapsamında incelendiğinde; Şirinevler Mahallesine tam anlamiyla, Yeni, Karşıyaka, Akyazı ve Şahincili Mahallelerine ise kısmen hizmet ettiği görülmüştür (Şekil 10).
Deniz kıyısı yerleşkesi olan Taşbaşı Mahallesi genel olarak eğimli bir yapıya sahiptir. 193.16 da yüz ölçümü ile Altınordu ilçesinin \%0.85'lik kısmını kapsamaktadır. 1368 kişi nüfusa sahip olan mahallede nüfus yoğunluğu $7 \mathrm{kişi} / \mathrm{km}^{2}$ dir. Mahalle 1979 yılında "Gayrimenkul Eski Eserler ve Anıtlar Kurulu" tarafindan bir kismı kentsel sit alanı ilan edilmiştir. Mahallede toplamda 19.763 $\mathrm{m}^{2}$ alana sahip 2 park alanı bulunmakta (Şekil 9) olup kişi baş1 $14.4 \mathrm{~m}^{2}$ park alanı düşmektedir (Tablo 2). Erişilebilirlik anlamında Taşbaşı Mahallesine tamamen, sinir mahalleleri olan Kirazlimanı ve Zaferimilli Mahallelerine ise kısmen hizmet ettikleri tespit edilmiştir.

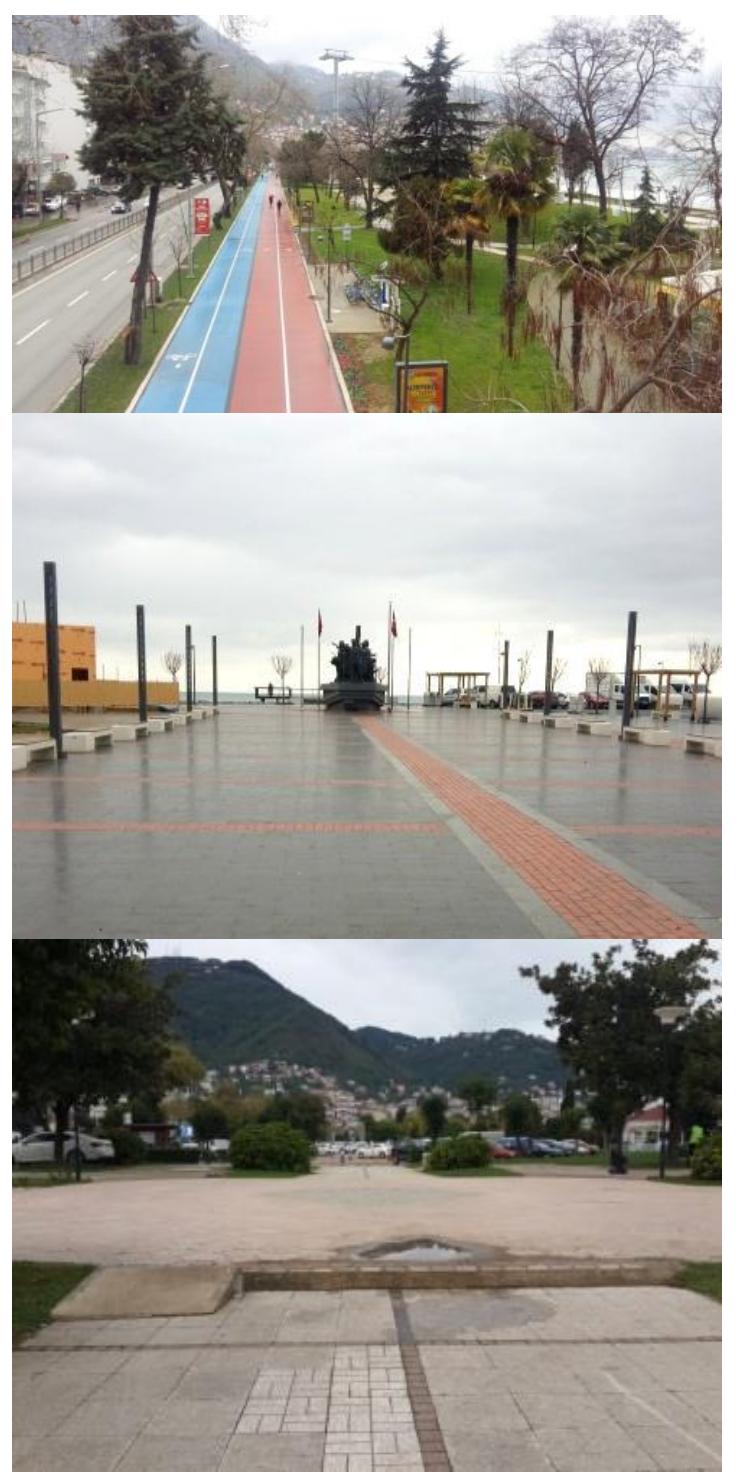

Şekil 8. Şarkiye mahallesi kıyı parkları

Kentin merkezi niteliğinde olan Yeni Mahalle 551.77 da yüz ölçümü ile Altınordu ilçesinin $\% 2.43$ 'lük alanını kaplamaktadır. Nüfusu 15444 kişi olan mahallede nüfus yoğunluğu 27 kişi $/ \mathrm{km}^{2}$ 'dir. Mahallede $600 \mathrm{~m}^{2}$ 'lik 1 adet park bulunmakta olup kişi başına $0.03 \mathrm{~m}^{2}$ park alanı düşmektedir. 


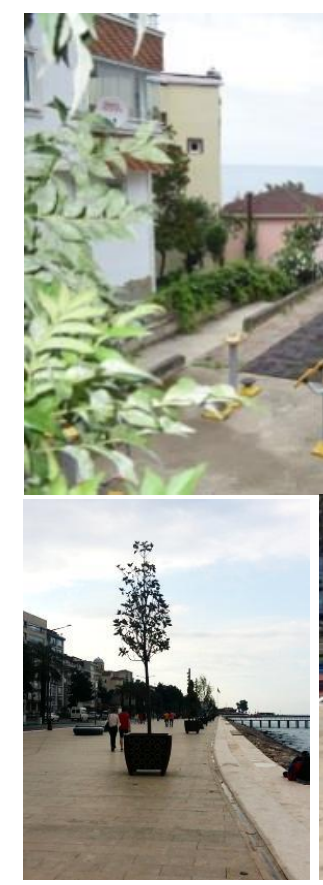

Şekil 9. Taşbaşı Mahallesi parkları genel görünümü
1979 y1lında "Gayrimenkul Eski Eserler ve Anitlar Kurulu" tarafindan bir kismı kentsel sit alanı ilan edilmiş eski yerleşim alanlarından biri olan Zaferimilli Mahallesi, 160.11 da yüz ölçümüne sahip olan Altınordu ilçesinin \%0.70'lik kısmını kapsamaktadır. Nüfusu 1285 kişi olan mahallede nüfus yoğunluğu $8 \mathrm{kişi} / \mathrm{km}^{2}$ 'dir ve mahallede park bulunmamaktadır. Mahallede kişi başına $2.5 \mathrm{~m}^{2}$ park alanı standardının sağlanması için $3212 \mathrm{~m}^{2}$ lik park alanı oluşturulması gerekmektedir.

40 mahalleden oluşan Altınordu'da, ilçe merkezini oluşturan 22 mahallenin toplam nüfusu 172878 kişidir ve kişi başına $2.40 \mathrm{~m}^{2}$ park alanı düşmektedir. Pamay (1978)'a göre kişi başına düşmesi gereken ortalama $2.50 \mathrm{~m}^{2}$ park alanı standardının altında kalan ilçede, standarda ulaşılması için toplamda $15620 \mathrm{~m}^{2}$ lik park alanına daha ihtiyaç duyulmaktadır (Tablo 2).

Tablo 2. Altınordu ilçesi parkları ve yeterlikleri analizi

\begin{tabular}{|c|c|c|c|c|c|c|c|}
\hline Nitelik & Mahalle Adı & $\begin{array}{l}\text { Nüfus } \\
\text { (Kişi) }\end{array}$ & $\begin{array}{l}\text { Park } \\
\text { Sayis! }\end{array}$ & Alan $\left(m^{2}\right)$ & $\begin{array}{l}\text { Kişi Başına } \\
\text { Düşen Miktar }\end{array}$ & $\begin{array}{c}\text { Olması } \\
\text { Gereken } \\
\text { Alan }\left(\mathbf{m}^{2}\right) \\
\end{array}$ & $\begin{array}{c}\text { İhtiyaç } \\
\text { Duyulan } \\
\text { Alan }\left(\mathbf{m}^{2}\right) \\
\end{array}$ \\
\hline \multirow{9}{*}{ 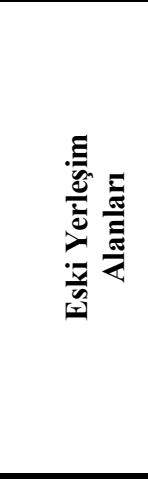 } & Aziziye & 930 & - & - & - & 2325 & 2325 \\
\hline & Bucak & 16642 & 7 & 5130 & 0.30 & 41605 & 36475 \\
\hline & Güzelyalı & 2286 & 1 & 2000 & 0.87 & 5715 & 3715 \\
\hline & Kirazlimanı & 1039 & 1 & 600 & 0.57 & 2597 & 1997 \\
\hline & Nizamettin & 4523 & 1 & 1000 & 0.22 & 11307 & 10307 \\
\hline & Selimiye & 9483 & 4 & 9800 & 1.03 & 23707 & 13907 \\
\hline & Subaş1 & 8532 & 2 & 2900 & 0.33 & 21330 & 18430 \\
\hline & Zaferimilli & 1285 & - & - & - & 3212 & 3212 \\
\hline & Yeni & 15444 & 1 & 600 & 0.03 & 38610 & 38010 \\
\hline \multirow{3}{*}{ 离 } & Düz & 1762 & 4 & 22860 & 12.90 & - & - \\
\hline & Saray & 1282 & 2 & 4750 & 3.70 & - & - \\
\hline & Şarkiye & 3781 & 1 & 53000 & 14.00 & - & - \\
\hline \multirow{5}{*}{ 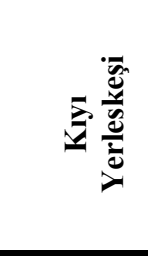 } & Akyazı & 17430 & 12 & 110354 & 6.33 & - & - \\
\hline & Bahçelievler & 8419 & 3 & 81450 & 9.67 & - & - \\
\hline & Durugöl & 8045 & 4 & 13395 & 1.66 & 20112 & 6717 \\
\hline & Kumbaş1 & 1705 & 3 & 5984 & 3.50 & - & - \\
\hline & Taşbaşı & 1368 & 2 & 19763 & 14.40 & - & - \\
\hline 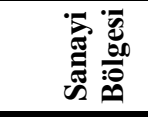 & Karapınar & 3355 & 3 & 8600 & 2.56 & - & - \\
\hline \multirow{4}{*}{ 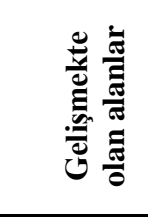 } & Cumhuriyet & 9379 & 5 & 13673 & 0.68 & 23447 & 9774 \\
\hline & Karşıyaka & 16195 & 5 & 12150 & 0.75 & 40487 & 28337 \\
\hline & Şahincili & 24426 & 8 & 24260 & 1.13 & 61065 & 33305 \\
\hline & Şirinevler & 15567 & 9 & 24306 & 1.56 & 38917 & 14611 \\
\hline Toplam & & 172878 & 78 & 416575 & 2.40 & 432195 & 15620 \\
\hline
\end{tabular}




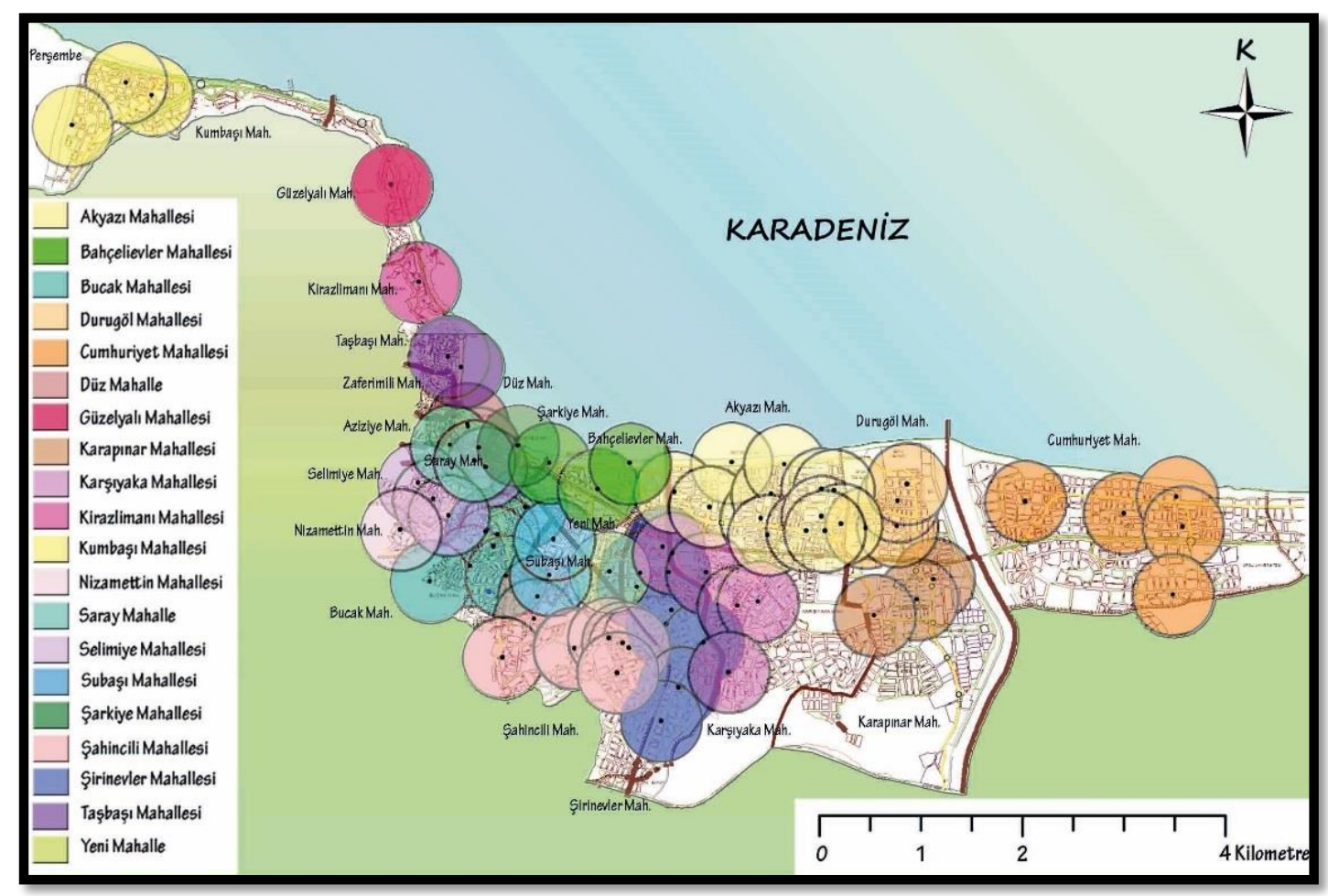

Şekil 10. Ordu kenti Altınordu ilçesi parklarının erişilebilirlik analizi

\section{Değerlendirme ve Öneriler}

$\mathrm{Bu}$ çalışma kapsamında, Ordu kenti Altınordu ilçesinde bulunan parkların, alansal yeterlilikleri ve erişilebilirlikleri incelenmiştir. İncelenen mahallelerin nüfusları ve park alanlarının yeterliliklerine bakıldığında 8 mahalle standartların üstünde, 12 mahalle standartların altında kalmaktadır.

Mahalleler mekansal karakterlerine göre değerlendirildiğinde; Altınordu ilçesinin ilk kuruluş yerleşimleri olan mahallelerde (Aziziye, Bucak, Güzelyalı, Kirazlimanı, Nizamettin, Selimiye, Subaşı, Zaferimilli) parkların nüfusa oranla yetersiz kaldığı tespit edilmiştir. Bucak ve Selimiye mahallelerinde bulunan parklar her ne kadar erişilebilir konumda olsalar da parklar alansal büyükleri ile sırasıyla $32 \mathrm{kişi} / \mathrm{km}^{2}$ ve 17 $\mathrm{kişi} / \mathrm{km}^{2}$ olan nüfus yoğunluğuna göre yeterlik gösterememektedir. Güzelyalı ve Kirazlimanı mahallelerinde nüfus yoğunluğu her ne kadar az olsa da mahallelerin topoğrafik koşulları, mevcut bulunan findık bahçeleri ve kuzey yönünden geçen E 70 karayoluna yakın olması mahalleleri sınırlandırmış ve gelişmelerine engel olmuştur. Bundan dolayı parklar mahalle nüfusuna oranla yetersiz kalmıştır.

Kent merkezi (Düz, Saray, Şarkiye) ve kıyı yerleşkesi olan mahallelerde (Akyazı, Bahçelievler, Kumbaşı, Taşbaşı), halkın sosyo- ekonomik yapısı, kıyı alanlarının çekiciliği ve mahallelerin topografik olarak düz bir yapıya sahip olmalarından dolayı bu mahallelerde parklar standartların üzerinde bir değere sahiptir. Aynı zamanda Akyazı ve Bahçelievler mahalleleri mekansal karakteri bakımından değerlendirildiğinde erişilebilir, yaşayanları açısından ihtiyaç duyulan hizmetlerin kaliteli olarak sunulduğu güvenli ve yaşayanları açısından aidiyet duygusu gelişmiş olmakla birlikte bu mahallelerde yaşayanlar genel olarak yüksek gelir grubuna sahiptirler.

Sanayi bölgesi olan Karapınar mahallesindeki parklar, alanın ticaret bölgesi olması ve nüfus yoğunluğunun az olmasından (1.63 kişi $\left./ \mathrm{km}^{2}\right)$ dolay1 mevcut nüfusa oranla yeterlik göstermektedir. Karapınar mahallesinde bulunan 3 adet park, mahallede bulunan yerleşim bölgeleri için ulaşılabilir özelliktedir. Park olmayan alanlar sanayi bölgesi olduğundan ve mahallede kişi başına $2.56 \mathrm{~m}^{2}$ park alanı düştüğünden mevcut parkların yeterli olduğu görülmüşsür.

Henüz yapısal ve nüfus yoğunluğu bakımından gelişimini tamamlamamış olan mahallelerde (Cumhuriyet, Karşıyaka, Şahincili, Şirinevler) bulunan parkların mevcut nüfusun ihtiyacını karşılayacak nitelikte olmadığ̣ görülmüştür.

Cumhuriyet mahallesinde yerleşim yoğun olarak kıyı bölümünde ve mahalleyi ikiye bölen E70 
karayolunun güney yönündedir. Kişi başına düşen park alanı standartlarına ulaşmak adına toplamda $9774 \mathrm{~m}^{2}$ olacak şekilde park alanına ihtiyaç duyulmaktadır. Yerleşim bakımından henüz gelişmekte olan bu mahalle nüfus yoğunluğu $\left(2.31 \mathrm{kişi} / \mathrm{km}^{2}\right)$ bakımından her ne kadar az olsa da mevcutta bulunan park alanları nüfusa göre yeterlik göstermemekle birlikte, homojen dağılmadıklarından erişilebilir olmadıkları belirlenmiştir.

Şahincili, Şirinevler ve Bucak mahallelerinde park say1s1 her ne kadar fazla olsa da parklar alansal olarak mahalle nüfusuna oranla yeterlik gösterememektedir. Standartlara ulaşılması adına mahallede bulunan kamusal alanların kullanıcı ihtiyaçlarına göre değerlendirilmesi ve bu alanlarda yapılacak olan düzenlemelerin hem yeşil alan miktarına katkı sağlayacak hem de mahalle sakinlerinin yararına olacak şekilde arttırılması gerekmektedir.

Karşıyaka mahallesindeki parkların bir aks üzerinde sıralandığı ve mahallede homojen olarak dağılmadığı görülmektedir. Kişi başına düşen park alanı miktarının standartların çok altında kaldığı ve mevcut parkların mahallenin tamamı açısından etkili hizmet alanı içinde olmamasından dolayı mahallede park sayısının 4 adet (her bir park yaklaşık $7.000 \quad \mathrm{~m}^{2}$ olacak şekilde) arttırılıp homojen bir şekilde dağıtılması gerekmektedir.

Ordu kenti için önemli bir kalite göstergesi olan parklar, nüfus oranına göre alansal yeterlikleri standartların altında kalmış olsa da Altınordu ilçesine büyük oranda hizmet ettikleri tespit edilmiştir. Alansal olarak standartlara ulaşılması adına farklı işlevsel yapıya sahip kentsel yeşil alan kullanımlarının mekânsal yeterlik ve erişilebilirlik açısından kent bütününde dengeli dağılımının sağlanması ve kent halkının yararlanmasına imkan sunacak rekreasyon alanlarını içerecek şekilde düzenlenmesi gerekmektedir.

Sonuç olarak; parkların planlama ve tasarım aşamalarında mahallelerin tarihsel gelişimleri ve kültürel özellikleri dikkate alınmalıdır. Alanın doğal özellikleri, arazi formu, nüfus yoğunluğu tespit edilmeli, parkların alan büyüklükleri ve formu bu özelliklere göre şekillendirilmelidir. Tüm mahalle halkına hitap edecek büyüklüğe sahip olan parklar mahalle içerisinde homojen olarak dağıtılmalı ve aynı zamanda erişilebilir olmalıdır. Mahalle nüfuslarının yaş grup dağılımları, sosyo-külturel özellikleri araştırılmalı ve parkları işlevsel hale getiren donatı elemanları, yeşil alanlar ve çocuk oyun alanları ihtiyaca yönelik biçimlendirilmelidir.

\section{Katkı Belirtme}

$\mathrm{Bu}$ çalışma, "Ordu Kenti Parklarının Peyzaj Mimarlığı Açısından İrdelenmesi” isimli yüksek lisans tezinden üretilmiştir.

\section{Kaynaklar}

Aksoy, Y., 2014. Türkiye'de Yeşil Alanlarla İlgili Yasal Düzenlemeler. İstanbul Ticaret Üniversitesi Fen Bilimleri Dergisi, 13(26), 1-20.

Anonim, 2012. Ordu İli Doğa Master Planı 2013-2023. T.C. Orman ve Su İşleri Bakanlığı, Doğa Koruma ve Milli Parklar Genel Müdürlügü. XI. Bölge Müdürlüğü Ordu Şube Müdürlüğü. Ordu.

Anonim, 2018. https://www.nufusu.com/il/ordu-nufusu (Erişim Tarihi: 14.11.2018).

Atabeyoğlu, Ö. ve Bulut, Y., 2012. Ordu Kenti Mevcut Yeşil Alanlarının Değerlendirilmesi. Akademik Ziraat Dergisi 1(2), 67-76

Aydemir, S.E., 2004. Kentsel Açık ve Yeşil Alanlar "Rekreasyon": Kentsel Alanların Planlanması ve Tasarımı. Akademi Yayın Evi, Ders Notları, Trabzon, 285-335.

Ersoy, M., 1994. Kentsel Alan Kullanım Normları. Ortadoğu Teknik Üniversitesi Mimarlık Fakültesi Basım İşbirliği, No: 92.02, Ankara, $301 \mathrm{~s}$.

Ersoy, M., 2015. Kentsel Planlamada Standartlar. Ninova Yayıncılık, 1. Basım, 335, İstanbul.

Francis, M., 2003. Urban Open Space, Desinging For User Needs, https://books.google.com.tr/books?hl=tr\&lr=\&i $\mathrm{d}=\mathrm{r} 4 \mathrm{vm} 8$ owZFbgC\&oi=fnd\&pg=PP11\&dq=urb an+open+space \&ots=cyrdVPZqJM\&sig=U175g uQx5qqIPLzZzHD8NqZ_Q\&redir_esc $=\mathrm{y} \# \mathrm{v}=\mathrm{on}$ epage $\& \mathrm{q}=u$ rban $\% 20$ open $\% 20$ space $\& \mathrm{f}=$ false (Erişim Tarihi: 07.11.2018).

Gül, A. ve Küçük, V., 2001. Kentsel Açık-Yeşil Alanlar ve Isparta Kenti Örneğinde İrdelenmesi. Süleyman Demirel Üniversitesi Orman Fakültesi Dergisi, (2), 27-48.

Gürsoy, B.D., 2018. Küçük Ölçekli Parkların Etki Alanlarına Kattığı Değerlerin ve Kullanım Potansiyellerinin İrdelenmesi İstanbul İli Beşiktaş İlçesi Örneği. Yüksek Lisans Tezi, İstanbul Teknik Üniversitesi, Fen Bilimleri Enstitüsü, Kentsel Tasarım Anabilim Dalı, İstanbul. 
Kandemir, R.V., 2010. Kamusal Alan İçerisinde Mahalle Parkları ve Bir Mahalle Parkı Tasarım Rehberi Düşüncesi. Yüksek Lisans Tezi, Mimar Sinan Güzel Sanatlar Üniversitesi, Fen Bilimleri Enstitüsü, Şehir ve Bölge Planlama Anabilim Dalı, İstanbul.

Kart, N., 2002. Emirgan Parkında Kullanıcıların Memnuniyet Derecelerinin Değerlendirilmesi. Yüksek Lisans Tezi, İstanbul Üniversitesi, Fen Bilimleri Enstitüsü, Peyzaj Mimarlığı Anabilim Dalı, İstanbul.

Mansuroğlu, S., 2002. Akdeniz Üniversitesi Öğrencilerinin Serbest Zaman Özellikleri ve Dış Mekan Rekreasyon Eğilimlerinin Belirlenmesi. Akdeniz Üniversitesi Ziraat Fakültesi Dergisi, 15(2), 53-62.

Nasuh, D., 1993. Kent Parklarının Nitelikleri ve Ankara Örneğinin İrdelenmesi. Yüksek Lisans Tezi, Ankara Üniversitesi, Fen Bilimleri Enstitüsü, Peyzaj Mimarlığı Anabilim Dalı, Ankara.

Pamay, B., 1978. Kentsel Peyzaj Planlaması, İstanbul Üniversitesi Yayınları, İstanbul.

Sherer, P.M., 2003. Why America Needs More City Parks and Open Space. The Trust for Public Land, 1-31.
Simonds, J.O., 1961. Landscape Architecture: The Shaping of Man's Natural Environ- ment. F.W. Dodge, New York, NY, 244 pp.

Tanrıverdi, F., 1987. Peyzaj Mimarlığı Bahçe Sanatının Temel İlkeleri ve Uygulama Metotları. Atatürk Üniversitesi, Bahçe Bitkileri Bölümü, Peyzaj Mimarlığı Anabilim Dalı Ders Kitabı, No: 49, Erzurum.

Thompson, C.W., 2002. Urban Open-Space in The 21st Century. Landscape and Urban Planning 60, 5972.

Uzun, G., 1990. Kentsel Rekreasyon Alanlarının Planlanması. Çukurova Üniversitesi, Ziraat Fakültesi, Ders Kitabı, No: 48. Adana.

Yenice, M.S., 2012. Kentsel Yeşil Alanlar İçin Mekânsal Yeterlilik ve Erişebilirlik Analizi; Burdur örneği, Türkiye. Türkiye Ormancılık Dergisi, 13(1), 41-47.

Yeşil, M. ve Yüksel, M., 2016. Ordu Kenti Örneğinde Kentlilik Bilinci. PARADOKS Ekonomi, Sosyoloji ve Politika Dergisi, 11, 43-65.

Yıldızcı, A.C., 1982. Kentsel Yeşil Alan Planlaması ve İstanbul Örneği. İ.T.Ü. Mimarlık Fakültesi. Basılmamış Doçentlik Tezi, İstanbul. 